\title{
Pulp Properties and Spent Pretreatment Solution Resulting from Reed Pulping with a Low Alkali Loading
}

\author{
Shuangshuang Zhao, ${ }^{\mathrm{a}}$ Zhongjian Tian, ${ }^{\mathrm{a}}{ }^{*}$ Gaojin Lyu, ${ }^{\mathrm{a}}$ Dongxing Wang, ${ }^{\mathrm{b}}$ Hairui Ji, ${ }^{\mathrm{a}}$ \\ Ruiming Wang, ${ }^{a}$ Xingxiang $\mathrm{Ji}^{\mathrm{a}},{ }^{, *}$ and Lucian A. Lucia ${ }^{\mathrm{a}, \mathrm{c}}$

\begin{abstract}
Using reed (Phragmites australis (Cav.) Trin. ex Steud) as raw material, straw pulp was prepared by low alkali (less than 6\%) pretreatment combined with mechanical grinding. The effects of pretreatment times and alkali dosages on pulp properties and pretreatment solution were investigated. The results demonstrated that alkali pretreatment affected FPI beating efficiency, and the beating energy consumption was lowest when pretreated with alkali dosage of $4 \%$. With $5 \% \mathrm{NaOH}$ pretreatment, the produced handsheets showed excellent properties that exceeded the requirements of food packaging paper and C-class corrugated paper. Moreover, low silicon content $(\leq 1.12 \mathrm{~g} / \mathrm{L})$ in the pretreatment liquor had an almost negligible effect relative to alkali recovery. Therefore, this study is important for researchers and industrial representatives seeking to use reed straw as material for pulping.
\end{abstract}

Keywords: Alkali pretreatment; Reed pulp; Pulp properties; Pretreatment Solution analysis

Contact information: a: State Key Laboratory of Bio-based Materials and Green Papermaking, Qilu University of Technology (Shandong Academy of Sciences), 3501 Daxue road, 250353, Jinan, China; b: Shandong Century Sunshine Paper Group Company Limited, Longjiao village north, development zone, Changle County, Weifang, China; c: North Carolina State University, Dept. of Forest Biomaterials, Raleigh, NC29675-8005, USA;

*Corresponding authors: tianzhj@qlu.edu.cn (Z.Tian);xxjt78@163.com (X. Ji)

\section{INTRODUCTION}

Wood is the main source of raw materials for the pulp and paper industry worldwide. Although non-wood raw materials are large reserves, their proportion in the raw materials of the paper industry has been only 5 to $7 \%$ (Navaee-Ardeh et al. 2004). As the demand for paper and paperboard increases, the paper industry develops rapidly, which results in a serious shortage of papermaking raw materials (Huang et al. 2007).

Reed, a relatively fast-growing and abundant grass biomass, has aroused considerable interest (El-Sayed et al. 2020). Each year, reed resources of $1000 \mathrm{~km}^{2}$ are readily available in the Liaohe Delta in northeastern China (Brix et al. 2014). As it comprises a large percentage of flexible cellulose fibers, it has potential to replace wood in pulp furnishes. Several reports about reed and its pulping and papermaking properties have been published in the past few decades (Shatalov and Pereira 2002; Wille et al. 2017). The characteristics of reed were analyzed from different sources and their different parts from the point of view of pulping, which is of great significance to avoid "silicon interference" (Pahkala and Pihala 2000; Finell and Nilsson 2005). A comparative study on bleachability of organic solvent-based (organosolv) pulping of giant reed was carried out, and the results showed that the ethanol-soda organosolv pulps from reed had higher bleaching response in comparison with traditional kraft pulping (Shatalov and Pereira 2006). In order to solve the transportation problem of reed raw materials, Finell et al. (2002) compared the pulp 
made from reed raw materials before and after compression. The work established the feasibility of compressed transportation of reed. Some other studies on reed organic solvents and soda-AQ pulping were also reported (Thykesson et al. 1998; Jimenez et al. 2002). However, there is limited data on the alkali-treated chemical mechanical pulping of reed, especially using a low alkali loading pretreatment.

On the other hand, China has recently completely banned the import of solid waste, and thus there was a shortage of secondary fiber resources represented by waste paper (Shen et al. 2019). In addition, replacing plastic with paper has also become a trend in China to meet the needs of sustainable development. Therefore, it is urgent for China to find renewable grass fiber raw materials for pulping and papermaking to make up for the shortage of wood and waste paper fibers. Reed has been used in pulping and papermaking in China for a long history. Brix et al. (2014) have reported on the production of reed resources in the Liaohe Delta of China and the feasibility and necessity of their application in papermaking. However, due to the pollution and energy consumption problems caused by the traditional grass-based pulping, reed as a pulping material has experienced a stagnation period for more than ten years in China. In view of the huge gap in China's papermaking raw materials and the demand for cleaner production, it is of great significance to restart the research on the clean pulping methods of grass-based raw materials represented by reeds.

In this study, reed straw (Phragmites australis (Cav.) Trin. ex Steud) was employed to produce pulp, using a low dosage alkali pretreatment and subsequent mechanical pulping. The influence of pretreatment parameters (times and alkali dosages) on pulp properties including tensile index, ring crush index, tear index, breaking length, compactness, whiteness, and yield of fine pulp were investigated. The pretreatment solution was analyzed. The feasibility of pulping using reed straw as material by a low dosage alkali pretreatment and subsequent mechanical method was demonstrated. Therefore, this study is important for researchers and industrial representatives seeking to produce pulp from grass biomass.

\section{EXPERIMENTAL}

\section{Materials}

Reed (Phragmites australis (Cav.) Trin. ex Steud) was harvested in mid-November from Dongying City, Shandong Province, China. Reed stalk was cut into small pieces of 5 $\mathrm{cm}$ and subsequently fibrillated in a screw extruder with a compression ratio of $4: 1$. The content of cellulose was determined by nitric acid-ethanol method, and the contents of hemicellulose, Klason lignin, and acid-soluble lignin were determined according to the Chinese national standards GB/T 2677.10 (1995), GB/T 2677.8 (1994), and GB/T 10337 (1989), respectively. The compositions of reed were $42.3 \%$ cellulose, $31.6 \%$ hemicellulose, $22.7 \%$ lignin, and 3.0\% silicon. Sodium hydroxide was supplied by Tianjin Damao Chemical Reagent Factory (Tianjin, China).

\section{Pulping}

Alkaline pretreatment

$\mathrm{NaOH}$ pretreatment was performed in a $1 \mathrm{~L}$ stainless reactor (GKCF-2, Yingyu

High Technique Instrument Factory, Gongyi, China). The mixture of $60 \mathrm{~g}$ of fibrillated reed stalk and $0.3 \mathrm{~L}$ of sodium hydroxide solution was heated to $100{ }^{\circ} \mathrm{C}$ for holding times 
of $20 \mathrm{~min}, 30 \mathrm{~min}$, and $40 \mathrm{~min}$. At the end of cooking, the pretreated solid and spent liquor were separated using a 200-mesh pulp bag. The solid was washed to a neutral $\mathrm{pH}$ with deionized water.

\section{Mechanical pulping}

Two-stage pulp grinding was carried out on a high consistency refiner with disc spacing of $0.5 \mathrm{~mm}$ and $0.15 \mathrm{~mm}$. The obtained pulp was stored in an incubator $(\mathrm{HH}-4$, Changzhou Guohua Electric Appliance Co., Ltd, Changzhou, China) for $30 \mathrm{~min}$ at $80{ }^{\circ} \mathrm{C}$ to facilitate pulp screening. After PFI beating of the unbleached pulp with a beating degree of $40 \pm 2{ }^{\circ} \mathrm{SR}$, handsheets with a basis weight of $100 \pm 5 \mathrm{~g} / \mathrm{m}^{2}$ were prepared according to the Chinese national standard GB/T 451.2 (2002).

\section{Reed Stalk and Pulp Fibers Characterization}

Surface morphological features

The surface morphological features of reed stalk were detected by a scanning electron microscope (Hitachi S-3400N, Tokyo, Japan) with an accelerating voltage of 5 to $10 \mathrm{kV}$. Small specimens of reed stalk were mounted in an orderly manner on stubs, sputtercoated with $15 \mathrm{~nm}$ palladium, and scanned to obtain images.

\section{Crystallinity index (CrI) of cellulose}

The crystallinity index $(C r I)$ of cellulose was measured with an X-ray diffractometer (XRD-6000, Shimadzu, Kyoto, Japan) using Ni-filtered $\mathrm{Cu}$ K $\alpha$ radiation (40 $\mathrm{kV}, 30 \mathrm{~mA})\left(2 \theta=5^{\circ}\right.$ to $40^{\circ}, \lambda=0.154184 \mathrm{~nm}$, scan speed $\left.=2^{\circ} / \mathrm{min}\right)$. The calculation was based on the following formula as Eq. 1,

$$
C I=\frac{I_{200}-I_{A M}}{I_{200}} \times 100 \%
$$

where $I_{200}$ and $I_{A M}$ are the diffraction intensities at $2 \theta=22.5^{\circ}$ and $18^{\circ}$, respectively.

\section{Pretreatment Solution Components}

Silicon

Silicon content of the raw material and the pulping spent liquor was determined with use of a UV Spectrophotometer by silicon-molybdenum blue spectrophotometry method according to Tong (2005) and Shi et al. (2004). The absorbance was determined at $680 \mathrm{~nm}$.

\section{Monosaccharide and lignin}

The concentrations of sugars in spent liquor were measured by ion chromatography (Dionex ${ }^{\text {TM }}$ ICS-5000, Thermo Fisher Scientific, Waltham, MA, USA) equipped with a RI detector and a separated column (CarboPac PA20, Thermo Fisher Scientific). The insoluble lignin content was determined by neutralizing the spent liquor to $\mathrm{pH} 2$ to precipitate the insoluble substances. After solid-liquid separation, the acid-soluble lignin content in liquor was measured on a UV Spectrophotometer at $205 \mathrm{~nm}$.

\section{Other chemical elements}

An energy dispersive spectrometer (EDS; Hitachi Xflash 6160) with an accelerating voltage of $10 \mathrm{kV}$ was used to analyze other chemical elements in pretreatment liquor. 


\section{RESULTS AND DISCUSSION}

\section{Analysis of Reed after Alkali Pretreatment}

To achieve environmentally sustainable production of pulp, low alkali loadings of 2 to $6 \mathrm{wt} \%$ were used to pretreat reed grass at $100{ }^{\circ} \mathrm{C}$. The reed composition after pretreatment was analyzed, and the results are shown in Table 1. The contents of cellulose, hemicellulose, lignin, and silicon all decreased with the strengthening of pretreatment conditions. For example, as the amount of alkali increased from $2 \%$ to $6 \%$, the contents of cellulose, hemicellulose, and lignin in the pretreated reed decreased from $42.1 \%, 31.0 \%$, $22.1 \%$ to $37.0 \%, 28.4 \%, 18.9 \%$, respectively.
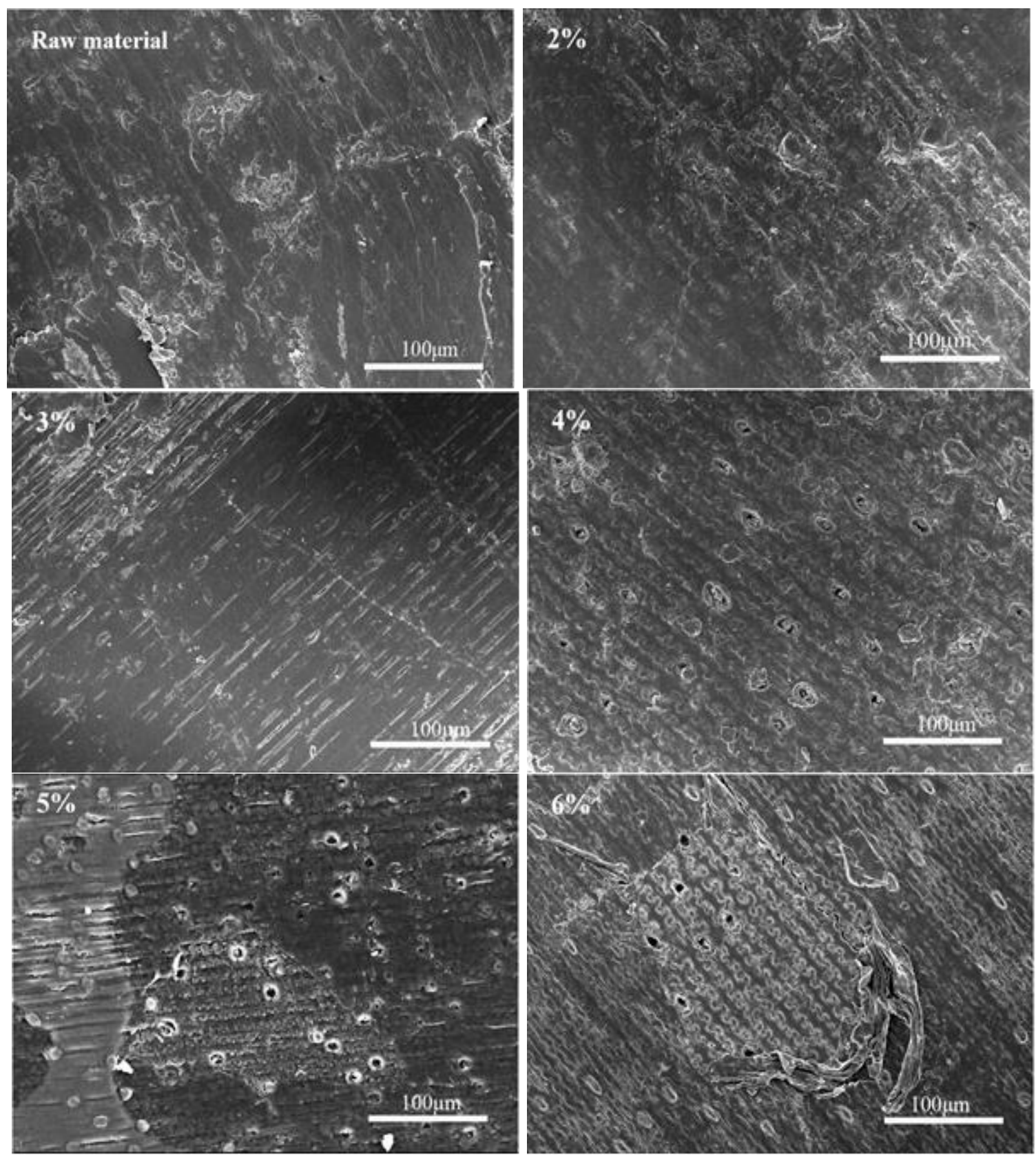

Fig. 1. Morphology of the pretreated Reed grass with different alkali loading 
Table 1. Solid Composition after Pretreatment

\begin{tabular}{|c|c|c|c|c|}
\hline $\begin{array}{c}\mathrm{NaOH} \\
\text { Loading }\end{array}$ & $\begin{array}{c}\text { Cellulose } \\
(\%)\end{array}$ & $\begin{array}{c}\text { Hemicellulose } \\
(\%)\end{array}$ & $\begin{array}{c}\text { Lignin } \\
(\%)\end{array}$ & $\begin{array}{c}\text { Silicon } \\
\text { Content } \\
(\%)\end{array}$ \\
\hline $2 \%$ & 42.1 & 31.0 & 22.1 & 2.9 \\
\hline $3 \%$ & 41.7 & 30.2 & 21.1 & 2.7 \\
\hline $4 \%$ & 40.7 & 29.9 & 20.8 & 2.4 \\
\hline $5 \%$ & 37.9 & 29.0 & 19.5 & 1.9 \\
\hline $6 \%$ & 37.0 & 28.4 & 18.9 & 1.8 \\
\hline
\end{tabular}

Figure 1 shows the surface features of the pretreated substrate. It could be seen that the pretreated reed stalk basically maintained its original shape, but the waxy and silicified film on the surface was damaged. The untreated reed grass displayed flat and intact cell walls. In contrast, visible structural damages with the formation of pores were observed on the cell walls of pretreated materials. As the employed alkali loadings increased to $6 \%$, numerous protuberances and cavities with different sizes appeared, which was related to the destruction of waxy and silicified coatings on the surface of reed straw.

Figure 2 shows the surface energy spectra of the reed straw before and after alkali pretreatment. Before alkali pretreatment, raw reed straw exhibited a uniform and flat silicon distribution. An obvious silicon dissolution and surface damage were observed after $5 \% \mathrm{NaOH}$ pretreatment. The resulting surface structures would be beneficial to mechanical pulping. Subsequently, the pretreated reed grass was ground using a high concentration pulping machine for two-stage pulping.

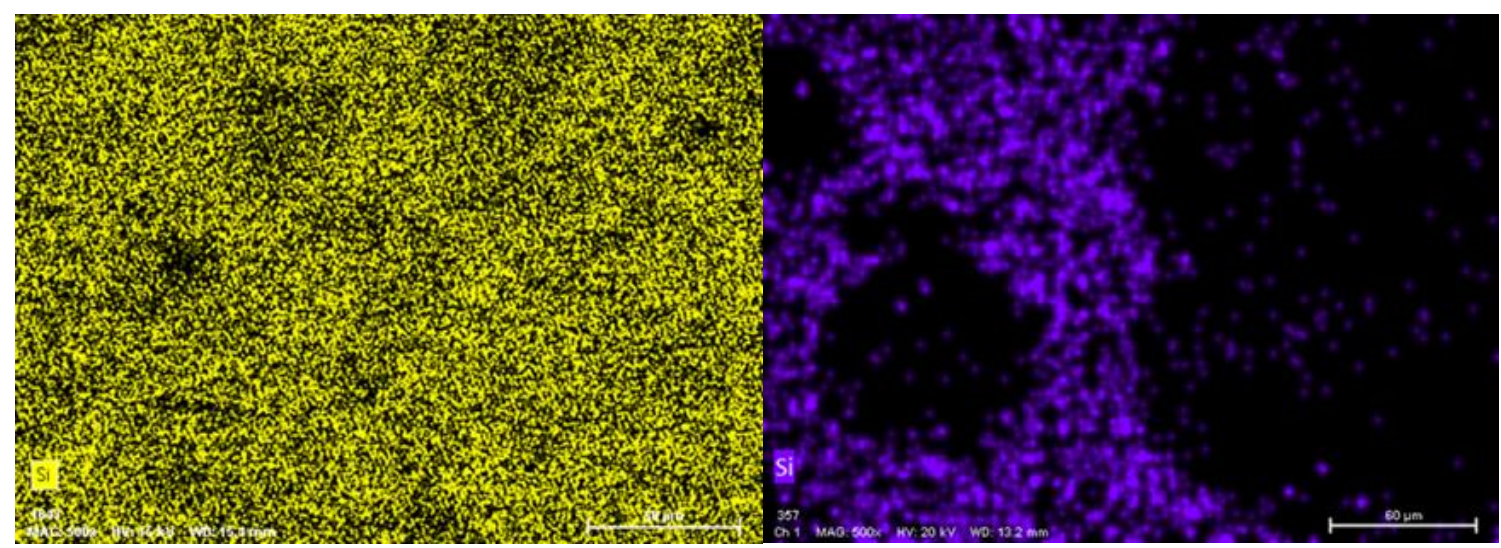

Fig. 2. Energy spectrum of the surfaces of raw reed straw (left) and pretreated straw with $5 \%$ $\mathrm{NaOH}$ (right)

\section{Pulp and Handsheets Properties}

After pulp screening and PFI beating, the accepted pulp was collected and used for handsheets preparation. Table 2 displays the properties of the obtained pulp and handsheets under different parameters. With increasing alkali loading to 5\%, the tensile index, ring crush index, tearing index, breaking length, and tightness increased to $31.12 \mathrm{~N} \cdot \mathrm{m} / \mathrm{g}, 9.11$ $\mathrm{N} \cdot \mathrm{m} / \mathrm{g}, 3.89 \mathrm{mN} \cdot \mathrm{m}^{2} / \mathrm{g}, 3.18 \mathrm{Km}$, and $0.42 \mathrm{~g} / \mathrm{m}^{3}$, respectively. High alkali dosage promoted the dissolution of protective matrix on straw surface and facilitated the cellulosic fibers fibrillation during pulping. More intermolecular hydrogen bonds were formed between fibers; thus, the properties of handsheets were improved. 


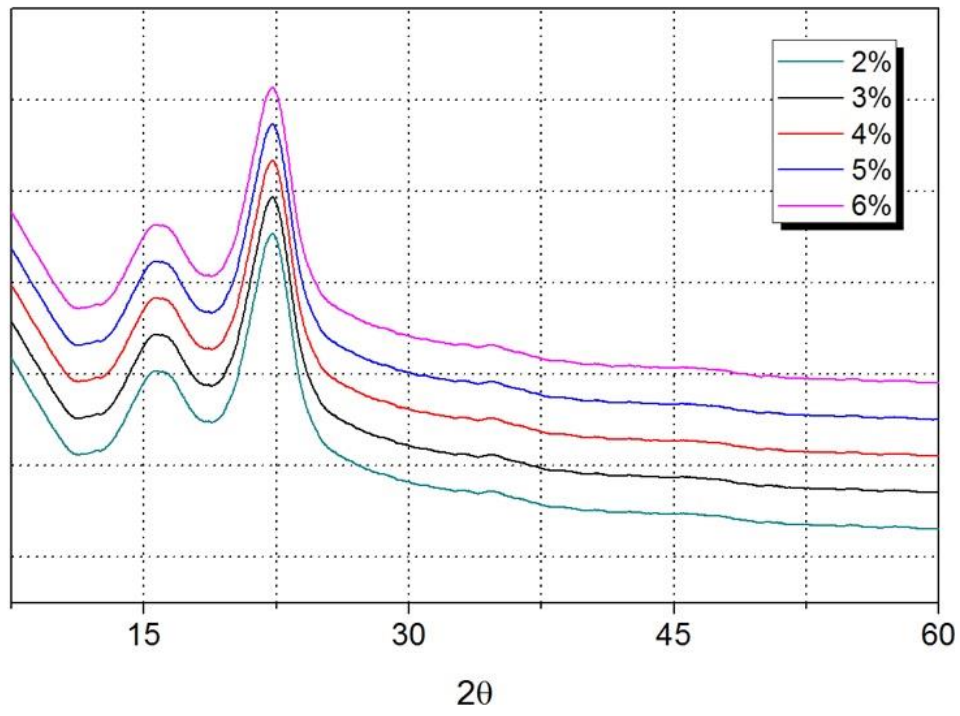

Fig. 3. XRD curves of the pretreated reed straw

The pretreatment did not cause an obvious change in CrI of cellulose. The CrI of pretreated reed straw was maintained above $65.17 \%$ (Fig. 3). However, the brightness and pulp accepts yield decreased to $34.20 \%$ ISO and $80.3 \%$, respectively. This result was mainly attributed to lignin oxidation and dissolution at high alkali loading. Interestingly, the total beating revolutions of each pretreated reed straw during PFI beating were very different, even when using the same beating degree of $40 \pm 2{ }^{\circ} \mathrm{SR}$. Less beating revolutions means a lower energy consumption. When alkali loading increased from $2 \%$ to $4 \%$, the total beating revolutions decreased from 7200 to $3400 \mathrm{rpm}$. Obviously, the alkali pretreatment contributed to the reduction of energy consumption of PFI beating. A light increase of total beating revolutions under $6 \%$ alkali dosage was attributed to the thick S1 layer and high fibers heterotropism of S2 layer in cell walls. Moreover, prolonging the pretreatment time had no remarkable effect on properties of pulp and handsheets, indicating that the alkali loading played a critical role during the removal of waxy and silicified coatings on the surface. Therefore, alkali pretreatment is an important factor affecting the beating efficiency of PFI. In this study, when the pretreatment alkali dosage was $4 \%$, the beating energy consumption was the lowest. In addition, the produced handsheets obtained after alkali pretreatment showed excellent properties. For example, the tensile index, the ring crush index, and the breaking length of the reed pulp obtained from $5 \% \mathrm{NaOH}$ pretreatment for $20 \mathrm{~min}$ were $31.12 \mathrm{~N} \cdot \mathrm{m} / \mathrm{g}, 9.11 \mathrm{~N} \cdot \mathrm{m} / \mathrm{g}$, and $3.18 \mathrm{~km}$ respectively, showing excellent properties that have exceeded the requirements of food packaging paper (the tensile index $\geq 26.5 \mathrm{~N} \cdot \mathrm{m} / \mathrm{g}$ according to the Chinese national standard QB/T1014-2010) and C-class corrugated paper (the ring crush index $\geq 3.80 \mathrm{~N} \cdot \mathrm{m} / \mathrm{g}$, and the breaking length $\geq$ $2.7 \mathrm{~km}$ according to the Chinese national standard GB13023-91).

\section{Pretreatment Solution Analysis}

As demonstrated in Fig. 2, NaOH pretreatment caused destruction of waxy and silicified coatings on the surface of reed straw. Increasing $\mathrm{NaOH}$ loading resulted in silicon dissolution into pretreatment liquor. Table 3 presents the results of the contents in the spent pretreatment liquor. 
Table 2. Properties of the Obtained Pulp under Different Parameters

\begin{tabular}{|c|c|c|c|c|c|c|c|c|c|c|}
\hline $\begin{array}{l}\text { Cooking } \\
\text { Time } \\
\text { (min) }\end{array}$ & $\begin{array}{l}\mathrm{NaOH} \\
\text { Loading } \\
(\%)\end{array}$ & $\begin{array}{l}\text { Pretreatment } \\
\text { Yield } \\
(\%)\end{array}$ & $\begin{array}{l}\text { Pulp } \\
\text { Accepts } \\
\text { Yield } \\
(\%)\end{array}$ & $\begin{array}{l}\text { Tensile } \\
\text { Index } \\
(\mathrm{N} \cdot \mathrm{m} / \mathrm{g})\end{array}$ & $\begin{array}{c}\text { Ring } \\
\text { Crush } \\
\text { Index } \\
(\mathrm{N} \cdot \mathrm{m} / \mathrm{g})\end{array}$ & $\begin{array}{l}\text { Tearing } \\
\text { Index } \\
\left(\mathrm{mN} \cdot \mathrm{m}^{2} / \mathrm{g}\right)\end{array}$ & $\begin{array}{l}\text { Breaking } \\
\text { Length } \\
(\mathrm{km})\end{array}$ & $\begin{array}{l}\text { Tightness } \\
\left(\mathrm{g} / \mathrm{m}^{3}\right)\end{array}$ & $\begin{array}{l}\text { Whiteness } \\
\text { (\%ISO) }\end{array}$ & $\begin{array}{l}\text { Beating } \\
\text { Revolutions } \\
\text { (rpm) }\end{array}$ \\
\hline \multirow{5}{*}{20} & 2 & 97.6 & 82.5 & 6.35 & 3.72 & 1.09 & 0.65 & 0.42 & 39.5 & 7200 \\
\hline & 3 & 97.2 & 82.3 & 15.35 & 5.78 & 2.03 & 1.57 & 0.34 & 37.7 & 5000 \\
\hline & 4 & 90.8 & 81.4 & 19.98 & 7.40 & 2.81 & 2.04 & 0.36 & 36.5 & 3400 \\
\hline & 5 & 87.7 & 80.3 & 31.12 & 9.11 & 3.89 & 3.18 & 0.42 & 34.2 & 4500 \\
\hline & 6 & 86.3 & 78.8 & 37.85 & 10.51 & 4.69 & 3.86 & 0.46 & 33.3 & 4500 \\
\hline \multirow{5}{*}{30} & 2 & 97.4 & 81.9 & 6.37 & 3.68 & 0.85 & 0.65 & 0.38 & 40.2 & 8000 \\
\hline & 3 & 96.3 & 81.8 & 11.20 & 5.09 & 1.64 & 1.14 & 0.38 & 37.6 & 5100 \\
\hline & 4 & 90.1 & 80.3 & 23.89 & 8.13 & 3.03 & 2.44 & 0.43 & 34.9 & 4500 \\
\hline & 5 & 87.3 & 79.8 & 27.98 & 9.07 & 3.39 & 2.85 & 0.44 & 34.4 & 4500 \\
\hline & 6 & 85.6 & 79.1 & 33.67 & 10.52 & 4.65 & 3.44 & 0.46 & 33.2 & 5100 \\
\hline \multirow{5}{*}{40} & 2 & 96.8 & 81.2 & 6.88 & 3.80 & 1.00 & 0.70 & 0.37 & 40.3 & 8200 \\
\hline & 3 & 95.3 & 80.7 & 13.39 & 5.45 & 1.90 & 1.37 & 0.39 & 37.5 & 5200 \\
\hline & 4 & 90.8 & 80.1 & 21.82 & 7.42 & 2.94 & 2.23 & 0.40 & 35.2 & 4600 \\
\hline & 5 & 87.1 & 79.9 & 28.97 & 9.03 & 4.02 & 2.96 & 0.41 & 34.1 & 5000 \\
\hline & 6 & 84.3 & 76.3 & 35.05 & 10.58 & 4.62 & 3.58 & 0.44 & 33.2 & 5200 \\
\hline
\end{tabular}


Through the determination of the $\mathrm{pH}$ value of the pretreatment solution, it could be seen that even when the amount of alkali reached $6 \%$, the $\mathrm{pH}$ value of the pretreatment solution was 11.58 , which is lower than that of the traditional semi-chemical pulping black liquor $(\mathrm{pH}>13)$. This confirmed the influence of the low-alkali loading (2 to $6 \%$ ) pretreatment in the present work. With $6 \%$ alkali dosage, the content of silicon reached $1.12 \mathrm{~g} / \mathrm{L}$ (Table 3). A dissolution process of silica in the alkaline solution can be explained by the formation of silicate. A high silicate content may cause serious silicon scaling during evaporation and concentration of alkali liquor and thus reduces alkali recovery efficiency (Zhang and Chen 2017). According to Xu and Li (2013), when the silicon content is in the range of $0.15 \%$ to $0.54 \%$, which is equivalent to the silicon content in wood pulping black liquor, there is no obvious silicon interference. The highest silicon content in the present pretreatment solution was $1.12 \mathrm{~g} / \mathrm{L}$, which is equivalent to $0.112 \%$ silicon in the pretreatment solution. So in this study, the effect of such a low silicon content on alkali recovery was almost negligible. Figure 4 demonstrates the elemental analysis of pretreatment liquor, mainly containing $\mathrm{C}, \mathrm{O}, \mathrm{Na}, \mathrm{Si}, \mathrm{Cl}$, and $\mathrm{K}$. No heavy metal elements were detected.

As $\mathrm{NaOH}$ penetrated the cell wall, the dissolution of lignin was improved. The silicon removal accompanied the delignification process according to Huang et al. (2007). Similar results were observed in this study. The maximum concentrations of acid-insoluble lignin (calculated based on the acid precipitated lignin, $\mathrm{pH}=2$ ) and acid soluble lignin in the pretreatment liquor were $15.19 \mathrm{~g} / \mathrm{L}$ and $3.25 \mathrm{~g} / \mathrm{L}$, respectively. $\mathrm{NaOH}$ pretreatment will remove part of lignin and degrade part of cellulose and hemicellulose. The most prevalent hemicellulose is xylan, composed of xylose units, 4-O-methyl-D-glucuronic acid, and ethanoic acid, which is attributed to degradation of ester units in the xylose. Other major components of hemicelluloses are mannan, galactoglucomannan, and arabinan (Bajpai 2018). Due to the weak pretreatment conditions, there was less degradation of cellulose and hemicellulose in the reed stalk. For example, when the alkali dosage reached $6 \%$, the concentrations of arabinose, glucose and xylose were only $2.03 \mathrm{~g} / \mathrm{L}, 1.96 \mathrm{~g} / \mathrm{L}$, and $10.55 \mathrm{~g} / \mathrm{L}$ (Table 3), respectively. This is also one of the reasons for the high pretreatment yield (Table 2 ). The monosaccharide in the pretreatment solution can be used to produce high valueadded products (Sjöström 1991). By removing the physical and chemical barriers from the protective surface layer and recalcitrant of hemicellulose and lignin, $\mathrm{NaOH}$ pretreatment facilitated subsequent defibrillation and PFI beating.

Table 3. Chemical Components in Pretreatment Liquor

\begin{tabular}{|c|c|c|c|c|c|c|c|}
\hline $\begin{array}{c}\mathrm{NaOH} \\
\text { Loading }\end{array}$ & $\begin{array}{c}\text { Arabinose } \\
(\mathrm{g} / \mathrm{L})\end{array}$ & $\begin{array}{c}\text { Glucose } \\
(\mathrm{g} / \mathrm{L})\end{array}$ & $\begin{array}{c}\text { Xylose } \\
(\mathrm{g} / \mathrm{L})\end{array}$ & $\begin{array}{c}\text { Acid- } \\
\text { insoluble } \\
\text { Lignin } \\
(\mathrm{g} / \mathrm{L})\end{array}$ & $\begin{array}{c}\text { Acid } \\
\text { Soluble } \\
\text { Lignin } \\
(\mathrm{g} / \mathrm{L})\end{array}$ & $\begin{array}{c}\text { Silicon } \\
\text { Content } \\
(\mathrm{g} / \mathrm{L})\end{array}$ & $\mathrm{pH}$ \\
\hline $2 \%$ & 0.59 & 1.12 & 2.24 & 2.52 & 1.70 & 0.11 & 9.74 \\
\hline $3 \%$ & 0.85 & 1.28 & 3.57 & 4.79 & 2.09 & 0.19 & 10.32 \\
\hline $4 \%$ & 1.22 & 1.50 & 5.31 & 8.01 & 2.53 & 0.35 & 10.60 \\
\hline $5 \%$ & 1.68 & 1.72 & 9.18 & 11.33 & 2.87 & 0.79 & 11.02 \\
\hline $6 \%$ & 2.03 & 1.96 & 10.55 & 15.19 & 3.25 & 1.12 & 11.58 \\
\hline
\end{tabular}




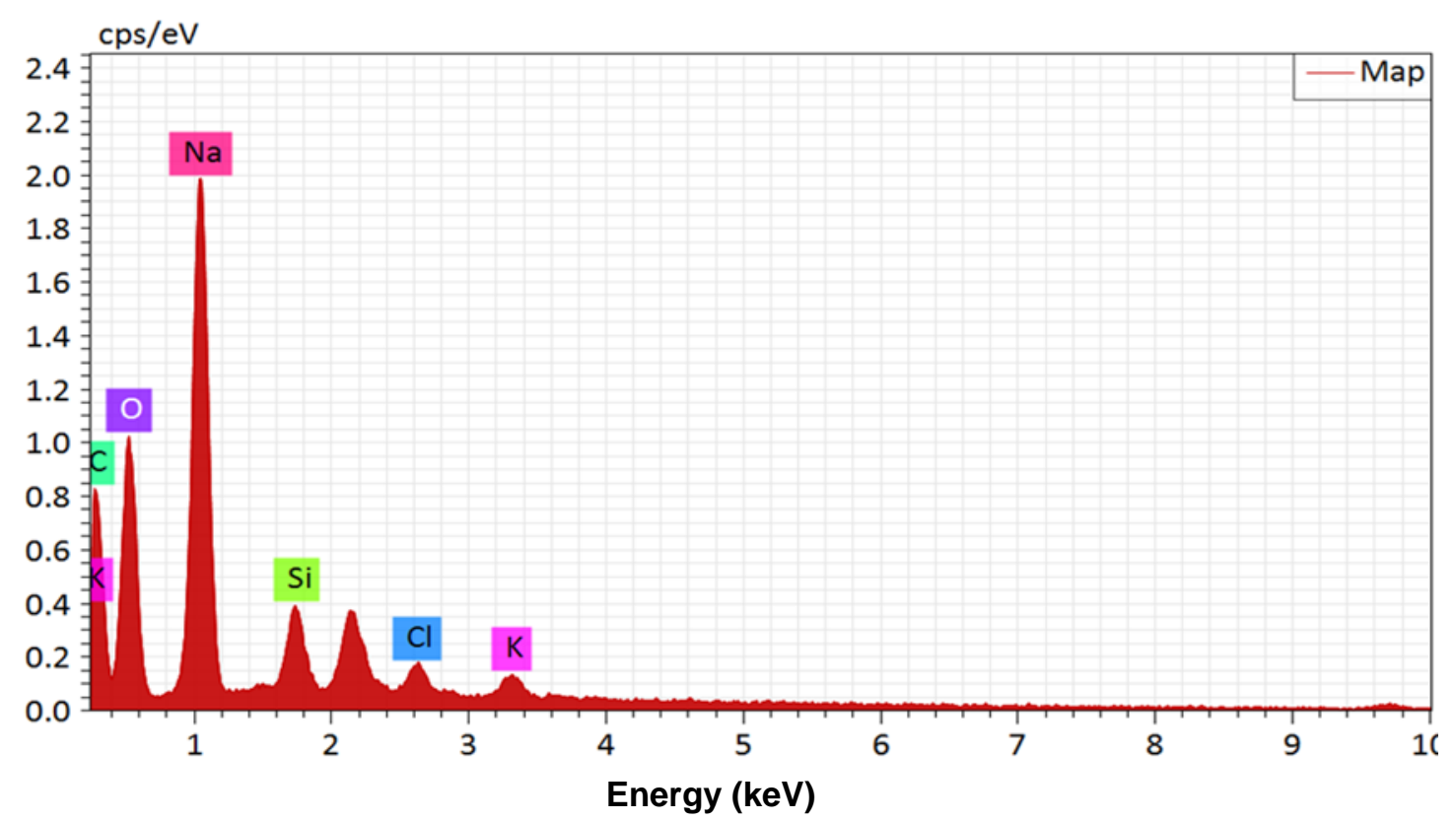

Fig. 4. Elemental analysis of pretreatment liquor

\section{CONCLUSIONS}

1. Chemical mechanical pulp from reed straw was produced. Pretreatment with low alkali loading (2 to 6\%) affected FPI beating efficiency, and the beating energy consumption was lowest when pretreated with alkali dosage of $4 \%$.

2. The produced handsheets derived from $5 \% \mathrm{NaOH}$ pretreatment showed excellent properties that have exceeded the requirements of food packaging paper and $\mathrm{C}$-class corrugated paper.

3. Low silicon content in the pretreatment liquor had an almost negligible affect for alkali recovery.

\section{ACKNOWLEDGMENTS}

The authors express thanks for support from the National Key R\&D Program of China, Grant No. 2019YFC1905900; National Natural Science Foundation of China, Grant No. 31670590, 31870566; Shandong Key Research and Development Program, Grant No. 2018YFJH0401 and 2018GGX108001; Taishan Scholars Program; and Yuandu Leading Talents Program.

\section{REFERENCES CITED}

Abd El-Sayed, E. S. A., El-Sakhawy, M. A., and El-Sakhawy, M. A. (2020). "Non-wood fibers as raw material for pulp and paper industry," Nordic Pulp and Paper Research Journal 35(2), 215-230. DOI: 10.1515/npprj-2019-0064 
Brix, H., Ye, S., Laws, E.A., Sun, D., Li, G., Ding, X., Yuan, H., Zhao, G., Wang, J., and Pei, S. (2014). "Large-scale management of common reed, Phragmites australis, for paper production: A case study from the Liaohe Delta, China," Ecological Engineering, 73, 760-769. DOI: 10.1016/j.ecoleng.2014.09.099

Bajpai, P. (2018). "Carbohydrate chemistry," in: Biermann's Handbook of Pulp and Paper (3 ${ }^{\text {rd }}$ Ed.), Elsevier, Ch. 17, pp. 363-371. DOI: 10.1016/B978-0-12-814240$0.00002-1$

Sjöström, E. (1991). "Carbohydrate degradation products from alkaline treatment of biomass," Biomass and Bioenergy 1, 61-64. DOI: 10.1016/0961-9534(91)90053-F

Finell, M., and Nilsson, C. (2005). "Variations in ash content, pulp yield, and fibre properties of reed canary-grass," Industrial Crops and Products 22(2), 157-167. DOI: 10.1016/j.indcrop.2004.08.003

Finell, M., Nilsson, C., Olsson, R., Agnemo, R., and Svensson, S. (2002). "Briquetting of fractionated reed canary-grass for pulp production," Industrial Crops \& Products 16(3), 185-192. DOI: 10.1016/S0926-6690(02)00036-5

Huang, G., Shi, J. X., and Langrish, T. A. G. (2007). " $\mathrm{NH}_{4} \mathrm{OH}-\mathrm{KOH}$ pulping mechanisms and kinetics of rice straw," Bioresource Technology 98(6), 1218-1223. DOI: 10.1016/j.biortech.2006.05.002

Jimenez, L., Perez, I., Lopez, F., and Ariza, J. (2002). "Ethanol-acetone pulping of wheat straw. Influence of the cooking and the beating of the pulps on the properties of the resulting paper sheets," Bioresource Technology 83(2), 139-143. DOI: 10.1016/S0960-8524(01)00196-1

Navaee, A. S., Mohammadi, R. J., and Pourjoozi, M. (2004). "Influence of rice straw cooking conditions in the soda-ethanol-water pulping on the mechanical properties of produced paper sheets," Bioresource Technology 92(1), 65-69. DOI: 10.1016/j.biortech.2003.07.006

Pahkala, K., and Pihala, M. (2000). "Different plant parts as raw material for fuel and pulp production," Industrial Crops \& Products 11(2), 119-128. DOI: 10.1016/S09266690(99)00050-3

Shatalov, A. A., and Pereira, H. (2005). "Arundo donax L. reed: New perspectives for pulping and bleaching. Part 4. Peroxide bleaching of organosolv pulps," Bioresource Technology 96(8), 865-872. DOI: 10.1016/j.biortech.2004.09.005

Shatalov, A. A., and Pereira, H. (2002). "Influence of stem morphology on pulp and paper properties of Arundo donax L. reed," Industrial Crops \& Products 15(1). DOI: 10.1016/S0926-6690(01)00098-X

Shen, K., Chen, Y,. Fang, G., Chen, W., Pan, A., and Zhang, F. (2019). “Analysis of global waste paper utilization and forecast of fiber supply and demand for China paper enterprises," China Pulp \& Paper Industry 40(21), 54-64

Shi, Y ., Li P., and Fang, G. (2004). "A fast quantitative determination method of silica content in paper making industry," Chemistry and Industry of Forest Products 38(1), $25-27$

Tong, G. (2005). "Spectrophotometeric determination of silicon in rice straw and black liquor after rice straw alkaline pulping by silicomolybdate blue," China Pulp \& Paper Industry (8), 64-66.

Thykesson, M., Sjoberg, L. A., and Ahlgren, P. (1998). "Paper properties of grass and straw pulps," Industrial Crops \& Products 7, 351-362. DOI: 10.1016/S09266690(97)10001-2 
Wille, V. K. D., Pedrazzi, C., Colodette, J. L., Oliveira, R. C. D., Coldebella, R., Giesbrecht, B. M., and Saccol, A. F. D. O. (2017). "Cellulose pulp produced from bulrush fiber," Ciência Rural 47(5). DOI: 10.1590/0103-8478cr20160652

$\mathrm{Xu}, \mathrm{Y}$., and Li, X. (2013). "Recent advance in non-wood fiber pulping technology for desilication," Journal of Shaanxi University of Science and Technology 3(1), 18-22.

Zhang, L., and Chen, K. (2017). "Pyrolysis behavior of the black liquor derived from soda-anthraquinone and soda-oxygen pulping of rice straw at different reaction end points," Energy \& Fuels 31(1), 514-522. DOI: 10.1021/acs.energyfuels.6b01735

Article submitted: November 10, 2020; Peer review completed: December 27, 2020;

Revised version received and accepted: January 30, 2021; Published: February 3, 2021. DOI: 10.15376/biores.16.2.2303-2313 